\title{
Test-retest reliability of baropodometry in young asyntomatic individuals during semi static and dynamic analysis
}

\author{
Confiabilidade teste-reteste da baropodometria em indivíduos \\ jovens assintomáticos durante análise semi estática e dinâmica
}

\author{
Rennie Alves, Wyngrid Porfirio Borel, Barbara Palmeira Rossi, Eduardo José Danza Vicente, \\ Paula Silva de Carvalho Chagas, Diogo Carvalho Felício*
}

\begin{abstract}
Introduction: Postural control is a multidimensional construct modulated by the integration of sensory information and muscular activity. One of the challenges in clinical practice and scientific research is the postural data collection of objective control data. Thus, baropodometry can be a promising instrument for analysis. Objective: To evaluate the absolute and relative reliability of baropodometry by means of test-retest in young asymptomatic subjects during semi-static and dynamic analysis. Methods: This is a methodological study, approved by the Research Ethics Committee of UFJF $(1,803,411)$. Sample selection was performed by convenience. Healthy individuals aged 18 to 35 years were included in the study without gender restriction. Participants with pain or any clinical signs of overload which led to unfeasible collection were excluded from the analysis. The variables analyzed were contact surface, maximum and mean pressure, index bow, pressure center and pressure areas in the forefoot, midfoot and hindfoot. Results: 33 individuals (total of $66 \mathrm{feet}$ ) participated in this study. The mean body mass of the participants was $63.0 \pm 9.9 \mathrm{~kg}$, height of $163.4 \pm 30.1 \mathrm{~cm}$, BMI of $23.7 \pm 2.8 \mathrm{~kg} / \mathrm{m}^{2}$.
\end{abstract}

\footnotetext{
RA: BS, e-mail: rennie.alves@gmail.com WPB: MS, e-mail: wyn_fisio@yahoo.com.br BPR: MS, e-mail: barrossi@hotmail.com EJDV: PhD, e-mail: eduardo.vicente@ufjf.edu.br PSCC: PhD, e-mail: paula.chagas@ufjf.edu.br DCF: PhD, e-mail: diogofelicio@yahoo.com.br
} 
It was observed that five out of the eight variables evaluated in the semi-static analysis presented high reliability ( $\geq 0.70$ ). On the other hand, the reproducibility of the measures in the dynamic analysis was low to moderate $(\leq 0.69)$. Conclusion: Baropodometry findings should be interpreted with caution in clinical practice and in scientific research. It is suggested that complementary assessments be made for decision-making assistance.

Keywords: Physical therapy. Reliability. Biomechanics.

\section{Resumo}

Introdução: O controle postural é um constructo multidimensional modulado pela integração de informações sensoriais e atividade muscular. Um dos desafios na prática clínica e em pesquisas científicas é a obtenção de dados objetivos do controle postural. Baseando-se nessa premissa, a baropodometria pode ser um instrumento promissor para esta análise. Objetivo: Avaliar a confiabilidade absoluta e relativa por meio de teste-reteste da baropodometria em indivíduos jovens assintomáticos durante análise semi estática e dinâmica. Métodos: Trata-se de um estudo metodológico, aprovado pelo Comitê de Ética em pesquisa da UFJF (parecer 1.803.411). A seleção da amostra foi por conveniência. Foram incluídos indivíduos hígidos de 18 a 35 anos sem restrição de gênero e excluídos participantes com queixa álgica ou qualquer sinal clínico de sobrecarga que inviabilizasse a coleta. As variáveis analisadas foram superfície de contato, pressão máxima e média, arco index, centro de pressão e as áreas de pressão no antepé, mediopé e retropé. Resultados: Participaram do estudo 33 indivíduos (66 pés). A média de massa corporal dos participantes foi de 63,0 $\pm 9,9 \mathrm{~kg}$, estatura de 163,4 $\pm 30,1 \mathrm{~cm}, I M C$ de $23,7 \pm 2,8 \mathrm{~kg} / \mathrm{m}^{2}$ e número do calçado 38,0 $\pm 2,1$. Observamos que das oito variáveis avaliadas na análise semi estática, cinco apresentaram confiabilidade alta (CCI $\geq 0.70)$. Por outro lado, a reprodutibilidade das medidas na análise dinâmica foi de baixa à moderada $(C C I \leq 0.69)$. Conclusão: Os achados da baropodometria devem ser interpretados com cautela na prática clínica e em pesquisa científica. Sugere-se que sejam realizadas avaliações complementares para o auxílio de tomada de decisões.

Palavras-chave: Fisioterapia. Confiabilidade. Biomecânica.

\section{Introduction}

The foot is an important structure of the locomotor system and it's responsible for maintaining postural stability and develops a crucial role in walking. Changes in gait pattern are predictive of musculoskeletal dysfunctions such as plantar fasciitis, patellar tendinopathy, trochanteric bursitis and low back pain [1, 2].

Postural control is a multidimensional construct modulated by the integration of sensory information and muscular activity. One of the challenges in clinical practice and in scientific research is the achievement of an objective postural control data. Based on this premise, baropodometry can be a promising instrument for analysis, as well as providing subsidies for interventions [3 - 5].
Baropodometry measures plantar pressure and may assist health professionals in the interpretation of posture and human movement. It is a simple, quick, low operating cost evaluation that is part of clinical and research protocols. The baropodometer allows semi-static and dynamic evaluations and, because it is a promising and little investigated tool, it is necessary the implementation of studies in order to evaluate its psychometric properties $[6,7]$.

Reliability is an important attribute of an instrument and refers to the consistency of the measurement in repeated administrations. A test that presents differentvaluesin subsequent measurements may lead to false conclusions about the results and, consequently, inappropriate clinical indications. The understanding of the psychometric properties of an evaluation improves the interpretation of the findings and favors clinical decision making [8-10]. 
It is emphasized that the reliability of a test is not a fixed property. Different instruments or samples may reveal different findings. Thus, the objective of the present study was to evaluate the relative and absolute reliability in asymptomatic young individuals using the Baropodometric Modular Platform and gait analysis MPS Biomech $^{\circledR}$ (LorAnEngineering, Bologna, Italy) through test-retest during semi-static and dynamics analysis.

\section{Methods}

Study design and ethical aspects

This is a methodological study. The research project was approved by the Research Ethics Committee of UFJF under opinion 1,803,411/2016. All the subjects were informed about the research objectives and the volunteers who agreed to participate signed the informed consent form.

\section{Sample}

The sample selection was of convenience. The sample size was estimated considering $\mathrm{HO}=0.4$, $\mathrm{H} 1=0.75, \alpha=0.05, \beta=0.2, \mathrm{n}=2$ [11] resulting in at least 33 individuals. Healthy Individuals were included in this study, 18 to 35 years of age without gender restriction. Participants who presented pain or any clinical signs of overload such as excessive sweating, dizziness and fatigue that made collection unfeasible were excluded.

\section{Instruments and procedures}

For the test-retest analysis the Baropodometric Modular Platform and Gait Analysis MPS Biomech ${ }^{\circledR}$ (LorAnEngineering, Bologna, Italy) [12] were used, composed of four modules connected in series, each with a dimension of $675 \times 540 \mathrm{~mm}, 2,304$ resistance sensors, frequency up to $100 \mathrm{~Hz}$, active area of $480 \times 480 \mathrm{~mm}$, polycarbonate coated and USB connection.

A single experienced researcher in baropodometric evaluation led the collection of data. The interval between evaluations was one week following the international guidelines for methodological studies: The Guidelines for Reporting Reliability and Agreement Studies [9].

In order to characterize the sample, information regarding body mass, height and number of shoes were collected. A mechanical scale was used with previously calibrated footage system. Following this procedure, for the semi-static analysis, the participants were instructed to position themselves in orthostatic posture, barefoot, facing a walking path that preceded the platform and then walking and stopping in the first module for 15 seconds. Subsequently, for dynamic analysis, participants were instructed to wander on the walking path until the software captured at least one complete foot from each limb. No guidance was given on the direction of the gaze, distance between the feet, pitch length and speed.

The variables analyzed were contact surface $\left(\mathrm{cm}^{2}\right)$, maximum pressure $(\mathrm{KPa})$, mean pressure $(\mathrm{KPa})$, arc index (\%), pressure center $(\mathrm{mm})$ and the areas of the feet: \% A (forefoot), \% B (midfoot) and \% C (hindfoot).

\section{Statistical analysis}

A descriptive analysis of the data was performed with mean and standard deviation values. Hereafter, the relative reliability of the measurements was calculated by the Intraclass Correlation Coefficient (ICC), Two Way Random model, absolute CCI concordance (2.1). It was considered the reference values for the ICC, in the present study, as small reliability up to 0.25 ; low $0.26-0.49$; moderate 0.50 - 0.69; high $0.70-0.89$ and very high above 0.90 [9]. From the ICC, absolute reliability was determined by the Standard Measurement Error (SME). The analysis was performed using the statistical software SPSS program for Windows version 17.0.

\section{Results}

In total, 33 subjects (66 feet) participated in the study. The mean body mass of participants was $63.0 \pm 9.9 \mathrm{~kg}$, height of $163.4 \pm 30.1 \mathrm{~cm}$, BMI of $23.7 \pm 2.8 \mathrm{~kg} / \mathrm{m}^{2}$ and number of footwear $38.0 \pm 2.1$. Tables 1 and 2 are the descriptive values of the test and retest and the relative and absolute reliability of the measurements (Tables 1 and 2). 
Table 1 - Descriptive analysis of baropodometric variables, relative and absolute reliability during semi-static evaluation $(n=66)$

\begin{tabular}{lcccc}
\hline Variables & First evaluation & Second evaluation & ICC (2,1) & SME \\
\hline Surface $\left(\mathrm{cm}^{2}\right)$ & $87.0 \pm 12.1$ & $85.3 \pm 14.2$ & 0.76 & 6.46 \\
Maximum pressure $(\mathrm{kpa})$ & $197.6 \pm 34.6$ & $204.4 \pm 36.9$ & 0.52 & 24.78 \\
Mean pressure $(\mathrm{kpa})$ & $66.1 \pm 10.6$ & $67.2 \pm 10.5$ & 0.83 & 4.35 \\
Arc Index (\%) & $16.2 \pm 7.1$ & $15.2 \pm 7.7$ & 0.88 & 2.57 \\
COP $(\mathrm{mm})$ & $349.0 \pm 59.0$ & $345.6 \pm 55.8$ & 0.31 & 47.7 \\
\%A & $47.5 \pm 4.6$ & $48.1 \pm 5.1$ & 0.88 & 1.68 \\
$\% B$ & $16.2 \pm 7.1$ & $15.8 \pm 8.4$ & 0.76 & 3.81 \\
$\% \mathrm{C}$ & $36.1 \pm 4.2$ & $36.1 \pm 5.4$ & 0.46 & 3.55 \\
\hline
\end{tabular}

Note: ICC = Intraclass Correlation Coefficient; $\mathrm{SME}=$ Standard Measurement Error; $\mathrm{COP}=$ pressure center; $\% \mathrm{~A}=$ forefoot plantar pressure; $\% \mathrm{~B}=$ midfoot plantar pressure; $\% \mathrm{C}=$ hindfoot plantar pressure.

Table 2 - Descriptive analysis of baropodometric variables, relative and absolute reliability during the dynamic evaluation

\begin{tabular}{lcccc}
\multicolumn{1}{c}{$(\mathrm{n}=66)$} & First evaluation & Second evaluation & ICC $(2,1)$ & SME \\
\hline Variables & $101.9 \pm 16.0$ & $100.0 \pm 15.3$ & 0.65 & 9.26 \\
\hline Surface $\left(\mathrm{cm}^{2}\right)$ & $305.1 \pm 30.1$ & $303.6 \pm 25.4$ & 0.37 & 22.10 \\
Maximum pressure (kpa) & $132.9 \pm 18.0$ & $135.0 \pm 13.5$ & 0.50 & 11.25 \\
Mean pressure (kpa) & $17.3 \pm 15.4$ & $16.3 \pm 9.2$ & 0.33 & 10.38 \\
Arc Index (\%) & $48.6 \pm 5.8$ & $48.6 \pm 5.2$ & 0.56 & 3.65 \\
$\%$ A & $15.7 \pm 7.4$ & $16.3 \pm 9.2$ & 0.60 & 5.28 \\
$\%$ B & $35.6 \pm 3.6$ & $34.9 \pm 4.9$ & 0.41 & 3.30 \\
\hline C &
\end{tabular}

Note: ICC = Intraclass Correlation Coefficient; SME = Standard Measurement Error; COP = pressure center; \%A = forefoot plantar pressure; $\% \mathrm{~B}=$ midfoot plantar pressure; $\% \mathrm{C}=$ hindfoot plantar pressure.

\section{Discussion}

The present study aimed to evaluate the relative and absolute reliability of asymptomatic young subjects during semi-static and dynamic analysis. In the semi-static analysis, five of the eight variables evaluated presented high reliability (ICC $\geq 0.70$ ). On the other hand, in the dynamic analysis, the reproducibility of the measurements was low to moderate (ICC $\leq 0.69$ ).

Previous studies have investigated the reliability of plantar pressure measurements using other instruments $[8,10,13]$. However, it should be noted that the psychometric properties of a measure cannot be generalized. The Baropodometric Modular Platform and Gait Analysis MPS Biomech ${ }^{\circledR}$ (LorAnEngineering, Bologna, Italy) were selected because we did not find evidence in the literature about these properties with the selected population [12].
In clinical practice and in scientific research objective measures are desirable. It was chosen to investigate measures of plantar pressure for being a recent resource. Evidences on the subject are exponential and in several areas, such as injury prevention [14], insoles manufacture [15, 16], diabetic foot ulcers $[17,18]$ and evaluation of the efficacy of physiotherapeutic interventions [19-21]. In this way, baropodometry can contribute to the development of innovative theories.

Regarding the methodological aspects, in the present study, instructions regarding where to look, posture and gait were not performed, which is in agreement with previous studies [20, 22, 23]. It is noteworthy that laboratory analysis alone modifies patterns of posture and movement, known as the Hawthorne effect [24]. In this sense, only a few instructions in the perspective of not changing individual patterns were made. In addition, the 
evaluations were carried out over a period of one week, because overly long periods between the tests favors the change of patterns compromising the reliability of the results [9]. It was conjectured that different methodologies can have an impact on the interpretation of the results of each study.

Regarding the results of the semi-static analysis, it was observed that the results were satisfactory, five of the eight variables presented good reliability indexes. Other authors also aimed to study the semistatic balance in healthy subjects and the results were similar $[2,21,25]$. A study with 41 subjects also obtained similar results with healthy youngsters and satisfactory results also occurred in semi-static posture with open eyes reaching ICC scores $=0.90[2]$.

It should be noted that ascending musculoskeletal lesions come mainly from incorrect movement patterns. When comparing the descriptive analysis of the present study, it was observed that in the first semi-static evaluation, the mean foot surface was $87.0 \mathrm{~cm}^{2}$, contrasting with $101.9 \mathrm{~cm}^{2}$ of the first dynamic evaluation. If this variable was used to evaluate the medial longitudinal arch, the results would be absolutely distinct and could lead to mistaken decision making [26]. Furthermore, prospective studies have demonstrated that the selection of a footwear based on semi-static evaluations does not reduce the incidence of injuries [27]. Thus, it was postulated that the clinical reasoning should be based on the interpretation of the movement analysis.

Regarding the dynamic analysis, in the present study, the results were not satisfactory. Of the seven evaluated variables, none showed high or very high ICC values [9]. Human movement is a dynamic, multidimensional, interactive and integrative construct, influenced by many factors such as affective, cognitive, social and physical function. Postural adjustments do not result from rigid internal structures, but modifiable by time and learning [28, 29]. Walking occurs through a complex interaction which hinders the interpretation of reductionist analysis [30]. Therefore, it is difficult to find consistent results on the subject and what raises the need for complementary evaluations for the elaboration of a kinesiological-functional diagnosis.

The ICC should be complemented by using random error measures, in the present research we used SME. When analyzing the results, it was observed that for most of the variables the SME of the dynamic analysis was superior to that of the semi-static analysis. It is important to know the dispersion of values to infer about real clinical changes, that is, changes greater than the typical error of the measure. The complexity of the factors involved in the posture and movement associated to the lack of understanding of the psychometric properties of the instruments in the clinical practice of the physiotherapist represent an obstacle in the professional performance. Studies on the topic can contribute on elucidating existing gaps.

Among the limitations of the study, we highlight the restricted characteristics of the sample as age and absence of pain complaint, which restricts the generalization of the findings. We suggest that users of baropodometry pay attention to sensor technology, matrix resolution, data and calibration and collection procedures.

\section{Conclusion}

We infer that the reproducibility of the semi-static analysis is superior to the dynamics. The findings of baropodometry should be interpreted with caution in clinical practice and in scientific research. It is suggested that complementary assessments be made for decision-making assistance.

\section{References}

1. Barton CJ, Bonanno DR, Carr J, Neal BS, Malliaras P, Franklyn-Miller A, et al. Running retraining to treat lower limb injuries: a mixed-methods study of current evidence synthesised with expert opinion. Br J Sports Med. 2016;50(9):513-26.

2. Rugelj D, Hrastnik A, Sevšek F, Vauhnik R. Reliability of modified sensory interaction test as measured with force platform. Med Biol Eng Comput. 2015 Jun;53(6):525-34.

3. Rosário JL. Biomechanical assessment of human posture: a literature review. J Bodyw Mov Ther. 2014;18(3):368-73.

4. Rosário JL. A review of the utilization of baropodometry in postural assessment. J Bodyw Mov Ther. 2014;18(2):215-9. 
5. Valentini FA, Granger B, Hennebelle DS, Eythrib N, Robain G. Repeatability and variability of baropodometric and spatio-temporal gait parameters - results in healthy subjects and in stroke patients. Neurophysiol Clin. 2011;41(4):181-9.

6. Giacomozzi C. Appropriateness of plantar pressure measurement devices: a comparative technical assessment. Gait Posture. 2010;32(1):141-4.

7. Giacomozzi C, Leardini A, Caravaggi P. Correlates between kinematics and baropodometric measurements for an integrated in-vivo assessment of the segmental foot function in gait. J Biomech. 2014;47(11):2654-9.

8. Khanmohammadi R, Talebian S, Hadian MR, Olyaei G, Bagheri H. The relative and absolute reliability of center of pressure trajectory during gait initiation in older adults. Gait Posture. 2017;52:194-201.

9. Kotnerr J, Audigé L, Brorson S, Donner A, Gajewski BJ, Hróbjartsson A, et al. Guidelines for Reporting Reliability and Agreement Studies (GRRAS) were proposed. J Clin Epidemiol. 2011;64(1):96-106.

10. Cuccia AM. Validity and Reliability of Spatio-Temporal Gait Parameters in Adolescents. Iran J Pediatr. 2013;23(5):610-1.

11. Miot HA. Tamanho da amostra em estudos clínicos e experimentais. J Vasc Bras. 2011;10(4):275-8.

12. Peixoto JG, Dias AG, Miranda LM, Defilipo EC, Feitosa MB, Chagas PSC. Reliability analysis of static and dynamic plantar pressure measurements of children and youths with normal development. Fisioter Pesqui. 2017;24(1):46-53.

13. Hafer JF, Lenhoff MW, Song J, Jordan JM, Hannan MT, HillstromHJ. Reliability of plantar pressure platforms. Gait Posture. 2013;38(3):544-8

14. Anbarian M, Esmaeili H. Effects of running-induced fatigue on plantar pressure distribution in novice runners with different foot types. Gait Posture. 2016;48:52-6.
15. Pasini Neto H, Grecco LAC, Ferreira LAB, Christovão TCL, Duarte NAC, Oliveira CS. Clinical analysis and baropodometric evaluation in diagnosis of abnormal foot posture: A clinical trial. J Bodyw Mov Ther. 2015;19(3):429-33.

16. Hähni M, Hirschmüller A, Baur $H$. The effect of foot orthoses with forefoot cushioning or metatarsal pad on forefoot peak plantar pressure in running. J Foot Ankle Res. 2016;9:44.

17. Fernando ME, Crowther RG, Lazzarini PA, Sangla KS, Wearing S, Buttner P, et al. Plantar pressures are higher in cases with diabetic foot ulcers compared to controls despite a longer stance phase duration. BMC Endocr Disord. 2016;16(1):51.

18. Nozabieli AJ, Martinelli AR, Mantovani AM, Faria CR, Ferreira DM, Fregonesi CE. Análise do equilíbrio postural de indivíduos diabéticos por meio de baropodometria. Motricidade. 2012;8(3):30-9.

19. Oliveira AK, Borges DT, Lins CA, Cavalcanti RL, Macedo LB, Brasileiro JS. Immediate effects of Kinesio Taping $\left({ }^{\circledR}\right)$ on neuromuscular performance of quadriceps and balance in individuals submitted to anterior cruciate ligament reconstruction: A randomized clinical trial. J Sci Med Sport. 2016;19(1):2-6.

20. Deepashini H, Omar B, Paungmali A, Amaramalar SN, Ohnmar H, Leonard J. Reliability Study of Plantar Pressure Measurement Among Low Back Pain Patients Carrying Different Loads. Middle East J Sci Res. 2014;21(7):1044-50.

21. Baumfeld D, Baumfeld T, Rocha RL, Macedo B, Raduan F, Zambelli R, et al. Reliability of Baropodometry on the Evaluation of Plantar Load Distribution: A Transversal Study. Biomed Res Int. 2017;2017:5925137.

22. Izquierdo-Renau M, Pérez-Soriano P, Ribas-García V, Queralt A. Intra and intersession repeatability and reliability of the S-Plate ${ }^{\circledR}$ pressure platform. Gait Posture. 2017;52:224-6.

23. Fernández-Seguín LM, Mancha JAD, Rodríguez RS, Martínez EE, Martín BG, Ortega JR. Comparison of plantar pressures and contact area between normal and cavus foot. Gait Posture. 2014;39(2):789-92. 
24. McCambridge J, Kypri K, Elbourne D. In randomization we trust? There are overlooked problems in experimenting with people in behavioral intervention trials. J Clin Epidemiol. 2014;67(3):247-53.

25. Cuccio AM. Validity and reliability of spatio-temporal gait parameters in adolescents. Iran J Pediatr. 2013;23(5):610-1.

26. McPoil TG, Ford J, Fundaun J, Gallegos C, Kinney A, McMillan P, et al. The use of a static measure to predict foot posture at midstance during walking. Foot (Edinb). 2016;28:47-53.

27. Knapik JJ, Trone DW, Swedler DI, Villasenor A, Bullock $\mathrm{SH}$, Schimied E, et al. Injury reduction effectiveness of assigning running shoes based on plantar shape in Marine Corps basic training. Am J Sports Med. 2010;38(9):1759-67.
28. Boyer KA, Johnson RT, Banks JJ, Jewell C, Hafer JF. Systematic review and meta-analysis of gait mechanics in young and older adults. Exp Gerontol. 2017;95:63-70.

29. Mummolo C, Mangialardi L, Kim JH. Quantifying dynamic characteristics of human walking for comprehensive gait cycle. J Biomech Eng. 2013;135(9):91006.

30. Simonsen EB. Contributions to the understanding of gait control. Dan Med J. 2014;61(4):B4823.

Received in 08/22/2017

Recebido em 22/08/2017

Approved in 10/06/2017

Aprovado em 06/10/2017 